Ramesh Patel MD, Michael Lenczyk MD,

Raafat S. Hannallah MD, Willis A. McGill MD

\title{
Age and the onset of desaturation in apnoeic children
}

\begin{abstract}
Most patients undergoing general anaesthesia are apnoeic during laryngoscopy and tracheal intubation. This study determined the time until the onset of desaturation following preoxygenation in apnoeic infants, children, and adolescents. Fifty ASA physical status I patients, 2 days to $18 \mathrm{yr}$ of age, were studied. The patients were stratified into one of five groups according to age: Group I, 0-6 mo; Group II, 7-23 mo; Group III, 2-5 yr; Group IV, 6-10 yr; and Group V, 11-18 yr. Following induction of anaesthesia with halothane via mask or intravenous barbiturates, the ability of the anaesthetist to ventilate the lungs via the mask was ascertained and paralysis was accomplished with vecuronium $0.1 \mathrm{mg} \cdot \mathrm{kg}^{-1}$. Manual mask ventilation was maintained with oxygen and halothane. When end-tidal $\mathrm{N}_{2}$ decreased below $3 \%$ (minimum time two minutes), the face mask was removed. The time between the removal of the face mask and a decrease in oxygen saturation $\left(\mathrm{SpO}_{2}\right)$ from $99-100 \%$ to $90 \%$ was measured. Manual ventilation was then resumed and the trachea intubated. Desaturation started earlier in infants than in two- to five-year-old children 96.5 $\pm 12.7 \mathrm{sec}$ vs $160.4 \pm 30.7 \mathrm{sec}, P<0.0001)$. Children became desaturated faster than adolescents (160.4 土30.7 vs $382.4 \pm$ 79.9 sec, $P<0.0001$ ). The time required to reach $90 \%$ saturation correlated well with age by linear regression analysis $\left(r^{2}=0.88, P<0.0001\right)$. We conclude that the time to onset of desaturation following pre-oxygenation with mask ventilation increases with age in healthy apnoeic children. Adolescents can tolerate apnoea for longer than children, and infants exhibit desaturation faster than children.
\end{abstract}

\section{Key words}

ANAESTHESIA: paediatric;

VENTILATION: anaesthetics, effects of apnoea.

From the Department of Anesthesiology, Children's National Medical Center and George Washington University Medical

Center, Washington, D.C., U.S.A.

Work performed at Children's National Medical Center, Washington, D.C.

Address correspondence to: Dr. Ramesh Patel, Department of Anesthesiology, Children's National Medical Center, 111

Michigan Ave., N.W. Washington, D.C., 20010.

Accepted for publication 20th May, 1994.
La plupart des patients demeurent en apnée pendant la laryngoscopie et l'intubation. Cette étude précise lintervalle qui précède la désaturation après préoxygénation chez les nouveaunés, les enfants et les adolescents. Cinquante patients ASA I, âgés de deux jours à dix-huit ans, font partie de l'étude. Les patients sont répartis en cinq groupes selon leur âge: groupe I, 0-6 mois, groupe II, 7-23 mois; groupe III, 2-5 ans; groupe IV, 6-10 ans; groupe V, 11-18 ans. Après une induction au masque à l'halothane ou aux barbituriques intraveineux, l'habileté de ventiler les poumons au masque est constatée et la paralyse initiée avec du vécuronium $0,1 \mathrm{mg} \cdot \mathrm{kg}^{-1}$. La ventilation manuelle au masque est maintenue avec de l'oxygène et de l'halothane. Quand le $\mathrm{N}_{2}$ télé-expiratoire diminue sous $3 \%$ (en deux minutes au minimum), le masque est enlevé. On mesure lintervalle entre le retrait du masque et une baisse de la saturation en oxygène $\left(\mathrm{SpO}_{2}\right)$ de $99-100 \%$ à $90 \%$. On reprend la ventilation manuelle et la trachée est intubée. La désaturation débute plus rapidement dans les deux premiers groupes que chez les enfants de deux à cinq ans $(96,5 \pm 12,7 \mathrm{~s}$ vs $160,4 \pm 30,7 \mathrm{~s}, P<0,0001)$. Les enfants désaturent plus rapidement que les adolescents $(160,4 \pm 30,7$ vs $382,4 \pm 79,9$ s, $P<0,0001)$. Le temps nécessaire à l'atteindre $90 \%$ de désaturation présente une bonne corrélation avec l'âge comme le montre l'analyse de régression linéaire $\left(r^{2}=0,88, P<0,0001\right)$. Nous concluons que lintervalle qui précède la désaturation après la préoxygénation avec ventilation au masque augmente avec l'âge chez les enfants apnéiques en bonne santé. Les adolescents peuvent tolérer l'apnée plus longtemps que les enfants et les nourissons se désaturent plus rapidement que les enfants.

All patients who receive a muscle relaxant before tracheal intubation during general anaesthesia experience a variable period of apnoea during laryngoscopy and tracheal intubation. Apnoea begins when mask ventilation is stopped prior to tracheal intubation and ends following intubation when ventilation is resumed. Apnoea may also occur during procedures such as bronchoscopy. Although healthy adolescents can usually tolerate a period of apnoea without becoming desaturated, infants may not. Newborns may become desaturated even before an uncomplicated intubation can be accomplished. The purpose of this study was to examine the effect of age on time until onset of desaturation (apnoea time) following pre- 
TABLE Relationship between age and apnoea time $(n=50)$

\begin{tabular}{llcc}
\hline Group* & Age & $\begin{array}{l}\text { T90\% (sec) } \\
\text { Mean } \pm S D\end{array}$ & $\begin{array}{l}\text { T90\% }(\mathrm{sec}) \\
\text { Range }\end{array}$ \\
\hline I & $2 \mathrm{~d}-6 \mathrm{mo}$ & $96.5 \pm 12.7$ & $77 \pm 118$ \\
II & $7 \mathrm{mo}-23 \mathrm{mo}$ & $118.5 \pm 9.0$ & $79-163$ \\
III & $2-5 \mathrm{yr}$ & $160.4 \pm 30.7$ & $114-205$ \\
IV & $6-10 \mathrm{yr}$ & $214.9 \pm 34.9$ & $165-274$ \\
V & $11-18 \mathrm{yr}$ & $382.4 \pm 79.9$ & $185-490$ \\
\hline
\end{tabular}

*10 pts in each group.

oxygenation with $100 \%$ oxygen via mask ventilation in apnoeic, anaesthetized infants, children, and adolescents.

\section{Methods}

The protocol was approved by the Institutional Review Board, and informed written consent was obtained from parents. Patients were stratified into one of five study groups according to age. Group I, 0-6 mo; Group II, 7-23 mo; Group III, 2-5 yr; Group IV, 6-10 yr; and Group V, 11-18 yr.

No premedication was given. Anaesthesia was induced with oxygen and halothane via mask in $\mathbf{4 7}$ children with intravenous barbiturates in 13 patients. After placement of an intravenous catheter, vecuronium $0.1 \mathrm{mg} \cdot \mathrm{kg}^{-1}$ was administered. Manual ventilation via mask was continued via a semi-closed circle system with $100 \% \mathrm{O}_{2}$ for at least two minutes following paralysis. Oxygen saturation was measured by Nellcor ${ }^{\circledR}$ pulse oximeter set in mode 1. Appropriate size oxisensors (Nellcor ${ }^{\circledR}$ No. $\mathrm{N}-25$ for infants and No. D-20 for children and adolescents) were used. End-tidal nitrogen $\left(\mathrm{N}_{2}\right)$ was measured by placing the end of the sampling tube of a mass spectrometer (SARA ${ }^{\circledR}$ system - Allegheny International Medical Technology) under the mask near the nostril. The face mask was removed when end-tidal $\mathrm{N}_{2}$ was $<3 \%$ (after manual ventilation for at least two minutes). No attempt was made to alter the position of the patient's jaw or head. The time between removal of the face mask and a decrease in $\mathrm{SpO}_{2}$ from $99-100 \%$ to $90 \%$ (onset of desaturation/ apnoea time) was measured. Manual ventilation was then resumed. The trachea was intubated when $\mathrm{SpO}_{2}>98 \%$ was restored.

The relationships between the time to onset of desaturation and the patient's age and weight were analyzed by linear regression analysis, and the fit characterised by the correlation coefficient $r^{2}$. Equality of the correlation coefficient was investigated by Fisher's z-transform, and differences between mean apnoea times for different age groups by the two-sample $t$ test. Values are presented as the mean $\pm \mathrm{SD}$.

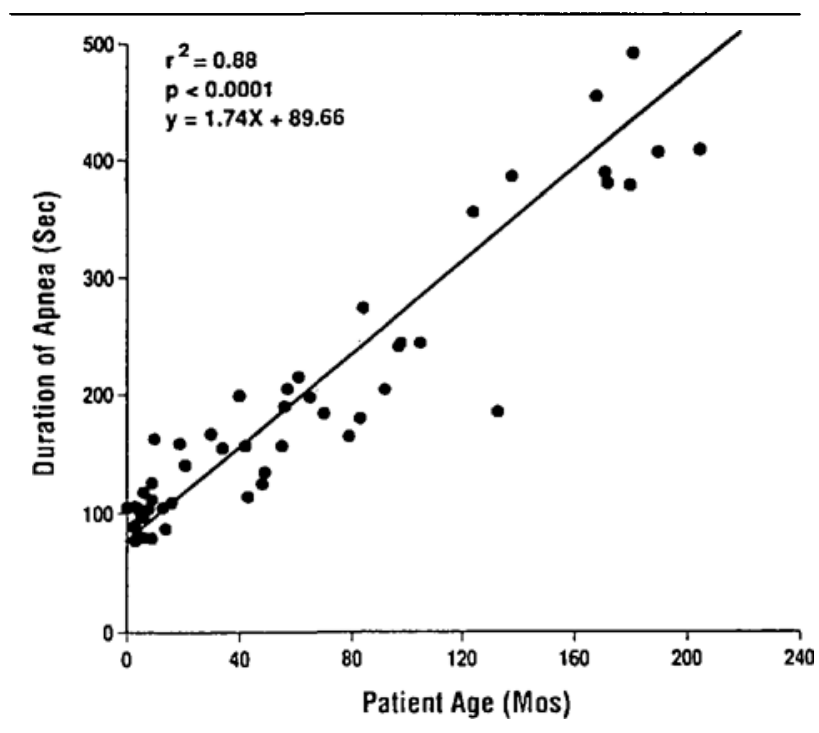

FIGURE 1 Relationship between duration of apnoea and patient age.

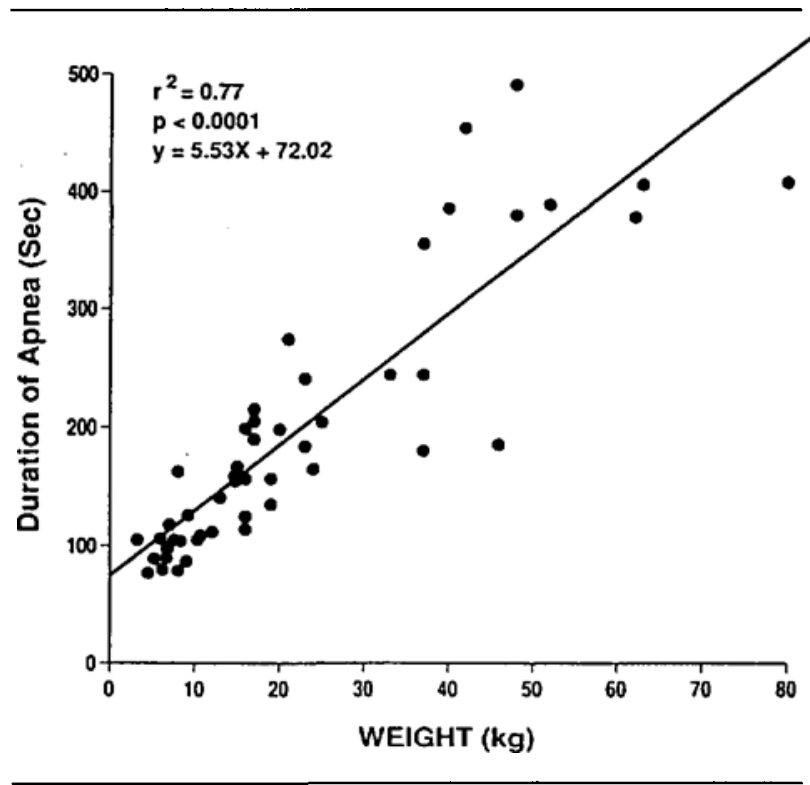

FIGURE 2 Relationship between duration of apnoea and patient weight.

\section{Results}

Fifty ASA physical status I patients, ranging in age from two days to $18 \mathrm{yr}$, were studied. Ten patients were included in each group. Results are summarized in the Table. All patients had an $\mathrm{SpO}_{2}$ of $99-100 \%$ at the start of apnoea. Scatter-plots were drawn of the duration of apnoea before onset of desaturation vs age (Figure 1) and weight (Figure 2). Close correlations were found between age and the time to onset of desaturation $\left(r^{2}=\right.$ 
$0.88, P<0.0001)$ and between weight and duration of apnoea $\left(\mathrm{r}^{2}=0.77, P<0.0001\right)$. After reinstitution of manual ventilation, $\mathrm{SpO}_{2}$ values continued to decline briefly in all patients before an upward trend was observed. The lowest $\mathrm{SpO}_{2}$ value observed in our study was $83 \%$. No arrhythmias or bradycardia were observed.

\section{Discussion}

Oxygen desaturation is relatively common in children undergoing general anaesthesia. In an apnoeic patient, the time to desaturation depends on the adequacy of preoxygenation, functional residual capacity (FRC) of the lungs, and oxygen consumption of the body. There is no agreement in the paediatric anaesthesia literature concerning the optimal duration or method of preoxygenation. Videira et al. ${ }^{\prime}$ concluded that a three-minute period of preoxygenation maintained $\mathrm{SpO}_{2}$ at a safe level for a longer time in children than a one-minute pre-oxygenation. In adults, preoxygenation at normal tidal volumes for three minutes leads to the same $\mathrm{PaO}_{2}$ values at the time of tracheal intubation as those achieved after similar breathing of $100 \%$ oxygen for five minutes. ${ }^{2} \mathrm{Al}-$ though healthy adult patients undergoing routine anaesthetic induction receive adequate protection against hypoxaemia with four maximal inspirations of oxygen, patients in whom a prolonged period of apnoea might occur after induction of anaesthesia should probably breathe oxygen for at least three minutes before the administration of anaesthetic drugs. ${ }^{3}$

Paediatric patients have smaller FRC in relation to closing volume and a relatively greater oxygen consumption rate than adults. The time to desaturation is, therefore, likely to be less in children than in adults. In infants undergoing rapid-sequence induction following preoxygenation, desaturation is not uncommon during laryngoscopy and intubation in spite of preoxygenation. The FRC in children correlates well with height, weight, and age; but there is no difference in FRC between the sexes. ${ }^{4-6}$ The ratio of FRC to body weight increases with age. ${ }^{4-6}$ Thorsteinsson $e t a l .^{5}$ reported that the ratio of FRC to body weight was $17 \pm 4 \mathrm{ml} \cdot \mathrm{kg}^{-1}$ in infants and $24 \pm 6 \mathrm{ml} \cdot \mathrm{kg}^{-1}$ in children more than one year of age. Oxygen consumption is relatively greater in younger than in older children..$^{7-9}$ Oxygen saturation decreases more rapidly in infants and children than in adults because the oxygen supply in the former is smaller, as a result of low FRC and higher rate of oxygen consumption.

Determination of the safe apnoeic period following preoxygenation (i.e., the time until oxygen saturation decreases to $90 \%$ ) is particularly critical in a patient who must undergo emergency surgery shortly after ingestion of food. To avoid gastric distension, mask ventilation is avoided. The trachea is intubated as soon as the patient is judged to be adequately anaesthetized and muscle relaxation complete. Based on their study of 61 patients between one month and $12 \mathrm{yr}$ of age, Kinouchi et al. ${ }^{10}$ concluded that $\mathrm{SpO}_{2}$ decreases to $95 \%$ more quickly in younger than in older children. In their study, the trachea was intubated after paralysis with vecuronium, and the lungs were manually ventilated. Apnoea was started by disconnecting the breathing circuit from the endotracheal tube. We initiated apnoea by removing the mask from the patient's face before intubation, because such a process more closely simulates the clinical situation during rapid-sequence induction.

The true importance of each desaturation incident depends on the duration of desaturation, level of $\mathrm{SpO}_{2}$, and the health of the patient. It is often difficult to evaluate the clinical importance of a brief, single $\mathrm{SpO}_{2}$ of $85 \%$. Coté et al. defined "major" events as those in which oxygen saturation was $<85 \%$ for $\geq 30 \mathrm{sec}$; "minor" events as $\mathrm{SpO}_{2}<85 \%$ for $<30$ sec. ${ }^{11,12}$ We chose a cutoff limit of $90 \%$ because many other recent studies have defined a saturation of $<90 \%$ as hypoxaemia or as significant desaturation. ${ }^{13-15}$

In healthy anaesthetized apnoeic adults, oxygen saturation decreases to $90 \%$ in $364 \mathrm{sec}$; in obese adults, desaturation occurs in $163 \mathrm{sec}^{16}$ By comparison, in infants and children (two days to ten years) desaturation occurs in 96-214 sec.

In conclusion, the results of this study confirm the clinical impression that infants and children become desaturated more raidly than adolescents. In infants, the time to desaturation may be so short as to allow only one attempt at intubation. If the first intubation attempt is unsuccessful, such patients may require mask ventilation. Time to onset of desaturation following ventilation with $100 \%$ oxygen increases with age among the paediatric surgical patients.

\section{References}

1 Videira RLR, Neto PPR, Gomide DO, Amarlal RV, Freeman $J A$. Preoxygenation in children: for how long? Acta Anaesthesiol Scand 1992; 36: 109-11.

2 Gold MI. Preoxygenation (Editorial). Br J Anaesth 1989; 62: 241-2.

3 Gambee AM, Hertzka RE, Fisher DM. Preoxygenation techniques: comparison of three minutes and four breaths. Anesth Analg 1987; 66: 468-70.

4 Gerhardt $T$, Reifenberg $L$, Hehre $D$, Feller $R$, Bancalari $E$. Functional residual capacity in normal neonates and children up to 5 years of age determined by a $\mathrm{N}_{2}$ washout method. Pediatr Res 1986; 20: 668-71. 
5 Thorsteinsson A, Jonmarker C, Larsson A, Vilstrup C, Werner $O$. Functional residual capacity in anesthetized children: normal values and values in children with cardiac anomalies. Anesthesiology 1990; 73: 876-81.

6 Bar-Yishay E, Shulman DL, Beardsmore CS, Godfrey S. Functional residual capacity in healthy preschool children lying supine. Am Rev Respir Dis 1987; 135: 954-6.

7 Lindahl SGE. Oxygen consumption and carbon dioxide elimination in infants and children during anaesthesia and surgery. Br J Anaesth 1989; 62: 70-6.

8 Schieber $R A$. Cardiovascular physiology in children. In: Motoyama EK, Davis PJ (Eds.). Smith's Anesthesia for Infants and Children, 5th ed., St. Louis: CV Mosby Co., 1990; 77-104.

9 Polgar G, Weng TR. The functional development of the respiratory system: from the period of gestation to adulthood. Am Rev Respir Dis. 1979; 120: 625-95.

10 Kinouchi K, Tanigami H, Tashiro C, Nishimura M, Fukumitsu $K$, Takauchi $Y$. Duration of apnoea in anesthetized infants and children required for desaturation of hemoglobin to $95 \%$. Anesthesiology 1992; 77: 1105-7.

11 Coté CJ, Goldstein EA, Coté MA, Hoaglin DC, Ryan JF. A single-blind study of pulse oximetry in children. Anesthesiology 1988; 68: 184-8.

12 Coté CJ, Rolf N, Liu LMP, et al. A single-blind study of combined pulse oximetry and capnography in children. Anesthesiology 1991; 74: 980-7.

13 Motoyama EK, Glazener $\mathrm{CH}$. Hypoxemia after general anesthesia in children. Anesth Analg 1986; 65: 267-72.

14 Pullerits J, Burrows FA, Roy WL. Arterial desaturation in healthy children during transfer to the recovery room. Can J Anaesth 1987; 34: 470-3.

15 Vijayakumar HR, Metriyakool K, Jewell MR. Effects of $100 \%$ oxygen and a mixture of oxygen and air on oxygen saturation in the immediate postoperative period in children. Anesth Analg 1987; 66: 181-4.

16 Jense HG, Dubin SA, Silverstein PI, O'Leary-Escolas $U$. Effect of obesity on safe duration of apnea in anesthetized humans. Anesth Analg 1991; 72: 89-93. 